\title{
HUBUNGAN STIMULASI DAN PENGETAHUAN ORANG TUA TERHADAP PERKEMBANGAN BAHASA PADA ANAK BALITA USIA 1-2,5 TAHUN DI PUSKESMAS I DENPASAR SELATAN
}

\author{
Ni Wayan Ari Adiputri \\ Program Studi D III Kebidanan, Politeknik Kesehatan Kartini Bali \\ Jl. Piranha No.2 Pegok Sesetan, Denpasar-Bali \\ E-mail : ari_adiputri@yahoo.com
}

Kata Kunci:

Stimulasi, Pengetahuan Orang

Tua, Perkembangan Bahasa

\begin{abstract}
ABSTRAK
Kemampuan berbahasa ada anak merupakan bentuk perkembangan anak yang paling komplek diantara kemampuan anak yang lain, karena hal tersebut terdapat banyak anak yang mengalami gangguan atau keterlambatan Bahasa. Desain penelitian ini adalah penelitian korelasi dengan pendekatan Crossectional. Penelitian ini telah dilaksanakan di Puskesmas I Denpasar Selatan. Besar sampel yaitu 40 orang, dengan menggunakan teknik purposive sampling. Data dikumpulkan dengan metode observasi langsung dengan alat pantau KPSP. Teknik analisis data yang digunakan adalah uji Chi-Square karena data tidak berdistribusi normal. Penelitian ini bertujuan untuk mengetahui hubungan stimulasi dan pengetahuan orang tua dengan perkembangan bahasa pada anak 1-2,5 tahun. Hasil penelitian ini didapatkan bahwa tidak terdapat hubungan antara stimulasi $(\mathrm{p}=0,477)$ dan pengetahuan orang tua $(\mathrm{p}=0,385)$ dengan perkembangan bahasa pada anak balita usia 1-2,5 tahun. Hasil penelitian ini diharapkan menjadi referensi untuk melakukan pemantauan pertumbuhan dan perkembangan bayi dan anak balita khususnya perkembangan bahasa di Puskesmas I Denpasar Selatan.
\end{abstract}

\begin{abstract}
Children's language skills are the most complex form of child development among other children's abilities, because of this, there are many children who experience language disorders or delays. The design of this study is a correlation study with a cross-sectional approach. This research has been conducted at Puskesmas I South Denpasar. The sample size is 40 people, using purposive sampling technique. Data were collected by direct observation with KPSP monitoring tools. The data analysis technique used is the Chi-Square test because the data are not normally distributed. This study aims to determine the relationship between parenting and language development in children 1-2.5 years. The results of this study found that there was no relationship between stimulation $(p=0.477)$ and parental knowledge $(p=0.385)$ with language development in toddlers aged 1-2.5 years. The results of this study are expected to be a reference for monitoring the growth and development of infants and toddlers, especially language development at Puskesmas I, South Denpasar.
\end{abstract}

\section{PENDAHULUAN}

Kemampuan berbahasa ada anak merupakan bentuk perkembangan anak yang paling komplek diantara kemampuan anak yang lain, karena hal tersebut terdapat banyak anak yang mengalami gangguan atau keterlambatan Bahasa. Keterlambatan bicara dab Bahasa dialami oleh 5-8 \% anak usia prasekolah. Dimana sebanyak $20 \%$ dari anak berumur 2 tahun mempunyai gagguan keterlambatan bicara dan gangguan berbahasa. Saat anak memasuki umur 5 tahun, terdapat 19 $\%$ dari anak-anak tersebut memiliki gangguan bicara dan Bahasa, 6,4 \% mengalami kelemahan berbicara, 4,6 \% kombinasi kelemahan bicara dan Bahasa, dan $6 \%$ memiliki kelemahan bahasa saja.[1] 
Permasalahan perkembangan anak yang sering dikeluhkan oleh orang tua adalah masalah keterlambatan bicara. Tetapi pada kenyataannya, permasalahan gangguan bicara dan bahasa pada anak ini sangat terlambat baru mendapat perhatian oleh orang tua. Sangat disayangkan adanya factor keterlambatan orang tua mengenal tentang tanda-tanda ganggaun bicara dan bahasa pada anak. Padahal jika orang tua secara optimal melakukan stimulasi pada anak tersebut maka proses perkembangan bahasa pada anak akan optimal sesuai dengan tahap perkembangan.[2]

Kemampuan anak dalam berbicara lebih dapat dinilai daripada kemampuan anak lainnya sehingga kemampuan bahasa lebih sering dikaitkan dengan kemampuan berbicara. Kemampuan anak dalam bahasa dan berbicara dipengaruhi oleh factor instrinsik ( dari dalam diri anak ) dan factor ekstrinsik ( dari lingkungan ). [3] Salah satu factor ekstrensik yaitu pemberian stimulasi perkembangan bahasa. Stimulasi yang diberikan pada anak harus seimbang baik dalam kualitas maupun kuantitas sesuai dengan tingkat pengetahuan anak.[4]

Permasalahan keterlambatan berbicara pada anak adalah permasalahan yang cukup serius dan harus segera ditangani karena merupakan satu penyebab keterlambatan perkembangan yang paling sering ditemukan pada anak. Keterlambatan berbicara dapat diketahui dari ketepatan penggunaan kata, yang ditandai dengan pengucapan yang tidak jelas dan dalam berkomunikasi hanya menggunakan bahasa isyarat, sehingga orang tua maupun orang yang berada di sekitar anak menjadi kurang dapat memahami anak tersebut, walopun si anak sebenarnya dapat memahami apa yang dibicarakan orang.[5]

Perkembangan bahasa pada anak inilah yang tidak diketahui oleh semua orang tua.
Fase-fase perkembangan bahasa setiap usia memiliki Batasan yang wajib diketahui oleh orang tua sebagai pemantauan akan perkembangan bahasa anaknya. Sehingga pengetahuan orangtua tentang perkembangan bahasa pada anak sangat diperluakn sebagai deteksi awal keterlambatan berbicara pada anak.[6]

Penelitian ini bertujuan untuk melihat hubungan stimulasi dan pengetahuan orang tau dengan perkembangan bahasa anak usai 1 2,5 tahun.

\section{TINJAUAN PUSTAKA}

Pola perkembangan anak dapat dilihat dari empat aspek yaitu motoric kasar, motoric halus, bahasa dan personal social. Aspek yang paling berperan dalam mengetahui keterlambatan pasa system lainnya yaitu kemampuan bahasa.[7]

Perkembangan bahasa merupakan suatu proses perkembangan pad anak yang mencakup aspek reseptif dan ekspresif. Aspek bahasa reseptif adalah kemampuan untuk mengerti apa yang dilihat dan didengar, sedangkan bahasa ekspresif adalah kemampuan berkomunikasi secara simbolik baik visual maupun auditorik.

Kemampuan berbahasa dan berbicara dipengaruhi oleh faktor intrinsic (dari anak) dan faktor ekstrinsik (dari lingkungan). Contoh faktor ekstrinsik berupa stimulus yang ada di sekeliling anak terutama perkataan yang didengar atau ditujukan kepada anak dan juga pengetahaun orangtua mengenai perkembangan bahasa.[8]

Stimulasi yang dapat diberikan berupa mendengarkan dan menyimak sebuah lagulagu kreasi daerah yang sangat sederhana. Dan hasilnya didapatkan bahwa 1) anak-anak mendengarkan dan menikmati lagunya; 2) anak-anak mengalami rasa senang dan bernyanyi Bersama; 3) anak-anak mau mengungkapkan pikiran mereka; 4) anak-anak 
mau belajar mengendalikan suara; 5) anakanak dapat menambah kosakata melalui lagulagu.[5]

Terdapat banyak bentuk stimulasi diantaranya dengan menggunakan media interaksi, DVD edukasi serta program televisi yang berbasis edutainment. Media ini sangat potensial untuk menjadikan suatu media berefek positif dan meminimalisir efek negatifnya. Dalam penelitiannya Rahmawati (2016) memberikan stimulasi media interaksi dan didapatkan bahwa terdapat peningakatan perkembangan yang bermakna sebelum dan sesudah diberikan intervensi media interaktif dengan nilai $\mathrm{P}=0,0001$. [7]

Pemberian stimulasi akan efektif apabila memperhatikan kebutuhan anak sesuai tahapan perkembangannya terutama apabila dilakukan pada periode kritis (Golden Period). Semakin dini stimulasi yang diberikan, maka perkembangan anak akan semakin baik. [9]

Pendidikan orang tua juga merupakan salah satu factor yang penting dalam pola asuh dan perkembangan bahasa, dengan Pendidikan yang baik maka orangtua akan memiliki pengetahuan yang baik dan mampu untuk menerima semua informasi terkait dengan perkembangan bahasa pada anak. [8] Sejalan dengan Soetjiningsih \& Ranuh, bahwa pengetahuan orang tua memiliki kebermaknaan terhadap perkembangan bahasa pada anak. [10]

Berdasarkan paparan diatas bahwa beberapa factor dari perkembangan bahasa yaitu stimulasi dan pengetahuan orang tua memiliki keterkaitan terhadap perkembangan bahasa pada anak-anak.

\section{METODE}

Penelitian ini merupakan penelitian korelasional yang bertujuan untuk melihat korelasi dari variabel independen dan variabel dependen dengan pendekatan cross sectional. Sampel dalam penelitian ini adalah anak balita yang berusia 1-2,5 tahun yang berada di wilayah kerja Puskesmas I Denpasar Selatan. Teknik sampling yang digunakan yaitu purposive sampling dengan instrument penelitian yaitu lembar kuesioner dan lembar pemantauan KPSP (kuesioner pra skrining perkembangan). Teknik analisa data menggunakan analisa chi-square.

\section{HASIL DAN PEMBAHASAN}

Tabel 1. Perkembangan Bahasa Anak 1-2,5 Tahun

\begin{tabular}{llcc} 
No & Katagori & Jumlah & Persentase \\
\hline 1 & Sesuai & 18 & $45 \%$ \\
\hline 2 & Tidak Sesuai & 22 & $55 \%$ \\
\hline & Jumlah & 40 & 100
\end{tabular}

Berdasarkan data di atas dapat diperoleh informasi bahwa sebagian besar responden $(55 \%)$ memiliki perkembangan bahasa yang tidak sesuai dengan usianya dan hampir setengahnya responden (45 \%) memiliki tumbuh kembang bahasa yang sesuai.

Hal ini sesuai dengan teori Chaer bahwa periode anak usia 1-2,5 tahun mulai mengucapkan perkataannya yang pertama meskipun belum lengkap dan pada masa ini beberapa kombinasi huruf masih sukar diucapkan seperti r,s,k,j dan t. Perkembangan bahasa pada anak juga dipengaruhi oleh banyak faktor yaitu faktor internal dan faktor ekternal.[3] Banyaknya responden yang memiliki perkembangan bahasa yang tidak sesuai dengan usianya, dan mengingat bahwa usia responden yang masih termasuk periode lingual dini sehingga akan menjadi langkah tepat untuk memberikan penanganan yang lebih intensif dalam mengatasi keterlambatan perkembangan bahasanya. Peran orang tua akan menjadi sangat penting dalam melakukan 
rangsangan kepada anak tersebut untuk meningkatkan kemampuan bahasanya.

Tabel 2. Hasil Uji Chi-square data Stimulasi dengan Perkembangan Bahasa pada Anak 1-2,5 Tahun

\begin{tabular}{|c|c|c|c|c|c|}
\hline \multirow[t]{3}{*}{ Katagori } & \multicolumn{4}{|c|}{ Perkembangan Bahasa } & \multirow[t]{3}{*}{$\mathbf{P}$} \\
\hline & \multicolumn{2}{|c|}{ Sesuai } & \multicolumn{2}{|c|}{$\begin{array}{l}\text { Tidak } \\
\text { Sesuai }\end{array}$} & \\
\hline & $\mathbf{F}$ & $\%$ & $\mathbf{F}$ & $\%$ & \\
\hline Stimulasi & & & & & 0,477 \\
\hline a. $\quad$ Dilakukan & 19 & 86,3 & 14 & 77,8 & \\
\hline $\begin{array}{ll}\text { b. } & \text { Tidak } \\
& \text { Dilakukan }\end{array}$ & 3 & 13,6 & 4 & 22,2 & \\
\hline
\end{tabular}

Berdasarkan data di atas terlihat bahwa stimulasi dengan nilai $\mathrm{p}=0,477$, hal ini menunjukkan nilai $\mathrm{p}<0,05$ yang bermakna Ho diterima dan $\mathrm{Ha}$ ditolak dan menyatakan bahwa tidak ada hubungan antara stimulasi dengan perkembangan bahasa pada anak 1-2,5 tahun.

Hal ini berbeda dengan teori dari Hurlock (2011), yang menyatakan bahwa kemahiran dalam bahasa dipengaruhi oleh faktor intrinsic yang bersumber dari anak dan faktor ektrinsik yang berupa stimulus yang ada di sekeliling anak terutama perkataan yang didengar atau ditujukan kepada anak dan juga pengetahuan orang tua tentang perkembangan bahasa.[3]

Hal ini didukung dengan penelitian Rahmawati (2016), yang menyatakan tidak ada hubungan yang bermakna antara perkembangan bahasa dengan stimulasi dari keluarga.[7] Pemberian stimulasi tambahan dapat meningkatkan perkembangan bahasa pada anak. Stimulus pada anak tidak hanya bersumber dari orangtua, melainkan perlunya ditambah atau dikombinasikan dengan menggunakan media tambahan seperti media interaktif, media flipcard. [11] Semakin banyak jeni stimulus yang diterima pada anak, maka anak akan lebih muydah untuk mengerti dan memahami.[12]

Jenis-jenis stimulasi pada anak balita dan anak prasekolah juga sangat penting. Pada masa ini merupakan masa untuk mempersiapkan diri menuju pembelajaran Pendidikan di sekolah. Bisa dibayangkan jika pada masa ini masih terjadi keterlambatan perkembangan bahasa, hal ini juga pastinya akan mempengaruhi ketrelambatan dari proses pembelajaran anak usia dini.[13]

Factor-faktor yang mempengaruhi perkembangan bahasa pada anak balita tidak hanya terfokus pada salah satu sumber permasalahan seperti faktor stimulus saja melainkan masih banyak fackor yang mempengaruhi.[3] Hal ini membuat para orangtua harus lebih banyak menggali dan menemukan penyebab munculnya keterlambatan. Dalam penanganannya pun orangtua harus rajin mencari informasi terkait dengan perkembangan bahasa.

\section{Tabel 3. Hasil Uji Chi-square data Pengetahuan Orang Tua dengan Perkembangan Bahasa pada Anak 1-2,5 \\ Tahun}

\begin{tabular}{|c|c|c|c|c|c|}
\hline \multirow[t]{3}{*}{ Katagori } & \multicolumn{4}{|c|}{ Perkembangan Bahasa } & \multirow[t]{3}{*}{$\mathbf{P}$} \\
\hline & \multicolumn{2}{|c|}{ Sesuai } & \multicolumn{2}{|c|}{$\begin{array}{c}\text { Tidak } \\
\text { Sesuai }\end{array}$} & \\
\hline & $\mathbf{F}$ & $\%$ & $\mathbf{F}$ & $\%$ & \\
\hline $\begin{array}{l}\text { Pengetahuan } \\
\text { Orang Tua }\end{array}$ & & & & & 0,385 \\
\hline a. Baik & 14 & 63,6 & 9 & 50 & \\
\hline b. Cukup & 2 & 9,1 & 2 & 11,1 & \\
\hline c. Kurang & 6 & 27,3 & 7 & 38,9 & \\
\hline
\end{tabular}

Berdasarkan data di atas terlihat bahwa pengetahuan orang tua dengan nilai $\mathrm{p}=0,385$, hal ini menunjukkan nilai $\mathrm{p}<0,05$ yang bermakna Ho diterima dan Ha ditolak dan menyatakan bahwa tidak ada hubungan antara pengetahuan orang tua dengan perkembangan bahasa pada anak 1-2,5 tahun.

Hal ini didukung oleh Safitri (2016) bahwa pengetahuan orang tua tidak langsung menimbulkan peningkatan perkembangan bahasa pada anak.[14] Pendidikan orangtua mendasari tingkat pengetahuan dari orangtua, apalagi terkait tentang penerimaan informasi tentang perkembangan bahasa pada anak.[15] Semakin tingginya tingkat Pendidikan orangtua, maka semakin banyak pula informasi yang diserap terkait perkembangan bahasa, hal ini lah yang mempengaruhi tingkat pengetahuan dari orangtua. Apabila dilihat secara langsung, pengetahuan orangtua tidak 
berhubungan secara langsung dengan perkembangan bahasa pada anak.[16]

Noviani (2018) dala penelitiannya juga berpendapat bahwa tidak terdapat hubungan yang bermakna antara tingkat pengetahuan orangtua tentang perkembangan bahasa dengan perkembangan anak balita. [17] Pengetahuan orang tua khususnya ibu dalam perkembangan bahasa walaupun menunjukkan secara analisis tidak berhubungan langsung, tetapi tetap penting untuk diketahui oleh para orang tua perjalanan perkembangan anak balita khususnya perkembangan bahasa.[18] Informasi yang semakin baik tentang perkembangan bahasa akan membuat para orang tua bisa memantau secara dini keterlambatan perkembangan khususnya perkembangan bahasa.

Perkembangan bahasa pada anak dipengaruhi oleh banyak faktor yang berada di sekitar anak, sehingga dalam mengatasi keterlambatan perkembangan bahasa tidak hanya terfokus ppada salah satu faktor saja.

\section{KESIMPULAN}

Hasil dari penelitian ini adalah tidak terdapat hubungan antara stimulasi dan pengetahuan orang tau dengan perkembangan bahasa pada anak usia 1-2,5 tahun. Saran perlu adanya pemantauan yang dilakukan baik dari pihak tenaga Kesehatan maupun dari orangtua, mengingat banyaknya factor lain yang mempengeruhi selain faktor stimulasi dan factor pengetahuan orang tua.

\section{DAFTAR PUSTAKA}

[1] E. Julianti, J. Natosba, N. R. Dewi, and A. Pangkalpinang, "PERKEMBANGAN BAHASA ANAK PRASEKOLAH DI TAMAN KANAK-KANAK KELURAHAN INDRALAYA RAYA," Jul. 2018. Accessed: Apr. 03, 2021. [Online]. Available:

http://jurnal.akperpangkalpinang.ac.id/i ndex.php/ejkp/article/view/27

[2] A. Yudia Putra, A. Yudiernawatti, and
N. Maemunah, "PENGARUH PEMBERIAN STIMULASI OLEH ORANG TUA TERHADAP PERKEMBANGAN BAHASA PADA ANAK USIA TODDLER DI PAUD ASPARAGA MALANG | Putra | Nursing News : Jurnal Ilmiah Keperawatan," J. Ilm. Keperawatan, vol. 3, no. 1, pp. 563-571, 2018, Accessed: Apr. 03, 2021. [Online]. Available:

https://publikasi.unitri.ac.id/index.php/fi kes/article/view/828.

[3] B. . Hurlock, Perkembangan Anak. Jakarta,Indonesia: Erlanggsa, 2011.

[4] S. Yusuf, Psikologi Perkembangan Anak dan Remaja. Bandung: PT. Remaja Rosdakarya, 2011.

[5] V. Anggraini, Y. Yulsyofriend, and I. Yeni, "Stimulasi Perkembangan Bahasa Anak Usia Dini Melalui Lagu Kreasi Minangkabau Pada Anak Usia Dini," Pedagog. J. Anak Usia Dini dan Pendidik. Anak Usia Dini, vol. 5, no. 2, p. 73, Nov. 2019, doi:

10.30651/pedagogi.v5i2.3377.

[6] W. Hapsari, L. Ruhaena, and W. D. Pratisti, "Peningkatan Kemampuan Literasi Awal Anak Prasekolah Melalui Program Stimulasi," J. Psikol., vol. 44, no. 3, p. 177, Dec. 2017, doi: 10.22146/jpsi.16929.

[7] W. Rahmawati et al., "PENGARUH STIMULASI MEDIA INTERAKTIF TERHADAP PERKEMBANGAN BAHASA ANAK 2-3 TAHUN," Faculty of Medicine, Diponegoro University, Semarang, Indonesia, 2016. doi: 10.14710/DMJ.V5I4.15982.

[8] Soetjiningsih and G. Ranuh, Tumbuh Kembang Anak. Jakarta,Indonesia: EGC, 2014.

[9] F. S. Hati and P. Lestari, "Pengaruh 
Pemberian Stimulasi pada

Perkembangan Anak Usia 12-36 Bulan di Kecamatan Sedayu, Bantul," J. Ners dan Kebidanan Indones., vol. 4, no. 1, p. 44, Jun. 2016, doi:

10.21927/jnki.2016.4(1).44-48.

[10] Z. Mulqiah, E. Santi, and D. R. Lestari, "POLA ASUH ORANG TUA DENGAN PERKEMBANGAN BAHASA ANAK PRASEKOLAH (USIA 3-6 TAHUN)," Dunia Keperawatan, vol. 5, no. 1, p. 61, Jul. 2017, doi: 10.20527/dk.v5i1.3643.

[11] R. Siti, A. Setyowati, and R. Itha Idhayanti, "MEDIA GAMBAR FLASHCARD DALAM MENSTIMULASI PERKEMBANGAN BAHASA ANAK USIA 3-4 TAHUN | Jendela Inovasi Daerah," J. Jendela Inov. Drh., vol. 1, no. 2, pp. 78-92, 2018, Accessed: Apr. 03, 2021.

[Online]. Available: http://jurnal.magelangkota.go.id/index.p $\mathrm{hp} /$ cendelainovasi/article/view/19.

[12] A. Handayani and A. Samiasih, "HUBUNGAN TINGKAT PENGETAHUAN ORANG TUA TENTANG STIMULASI VERBAL DENGAN PERKEMBANGAN BAHASA PADA ANAK PRASEKOLAH DI TK PGRI 116 BANGETAYU WETAN," 2013. Accessed: Apr. 03, 2021. [Online]. Available:

http://103.97.100.145/index.php/FIKke S/article/view/1876.

[13] Y. Ani, S. Dewi, S. Al, and H. Mojokerto, "PENINGKATAN PERKEMBANGAN BAHASA ANAK USIA DINI MELALUI METODE MEMBACA PADA PERMAINAN KARTU KATA," SELING J. Progr. Stud. PGRA, vol. 5, no. 2, pp. 208-216, Jul. 2019, Accessed: Apr. 04, 2021. [Online]. Available: http://www.jurnal.stitnualhikmah.ac.id/i ndex.php/seling/article/view/452.

[14] Y. Safitri, "Faktor-Faktor yang Berhubungan dengan Perkembangan Bahasa Balita di UPTD Kesehatan Baserah Tahun 2016," J. Obs. J. Pendidik. Anak Usia Dini, vol. 1, no. 2, p. 148 , Dec. 2017, doi: 10.31004/obsesi.v1i2.35.

[15] A. Candrasari, D. Eka Faulam Putri, and V. Parisa, "PENGARUH LINGKUNGAN TERHADAP PERKEMBANGAN BAHASA ANAK," in The 5th Urecol Proceedings, 2017, pp. 972-978.

[16] M. U A D D I B Vol, L. Sumaryanti, and M. Pd, "Lilis Sumaryanti, Peran Lingkungan PERAN LINGKUNGAN TERHADAP PERKEMBANGAN BAHASA ANAK," Muaddib Stud. Kependidikan dan Keislam., vol. 7, no. 01, pp. 72-89, Jul. 2017, Accessed: Apr. 04, 2021. [Online]. Available: http://journal.umpo.ac.id/index.php/mua ddib/article/view/552.

[17] E. Noviani and F. Zulaikha, "Hubungan Pola Asuh Orang Tua dan Tingkat Pengetahuan Orang Tua Tentang PerkembanganBahasa Balita, Anak Paud, Di Kerja, Wilayah Mangkupalas, Puskesmas," Universitas Muhammadiyah Kalimantan Timur, 2018 .

[18] M. B. Karo, "HUBUNGAN PENGETAHUAN DAN SIKAP IBU TERHADAP PERKEMBANGAN BAHASA ANAK USIA1-3 TAHUN (TODDLER) DI SEKOLAH NISRINA JATI ASIH KOTA BEKASI TAHUN 2013," 2018. Accessed: Apr. 04, 2021. [Online]. Available: https://ejournal.jurwidyakop3.com/index.php/ju rnal-ilmiah/article/view/229. 